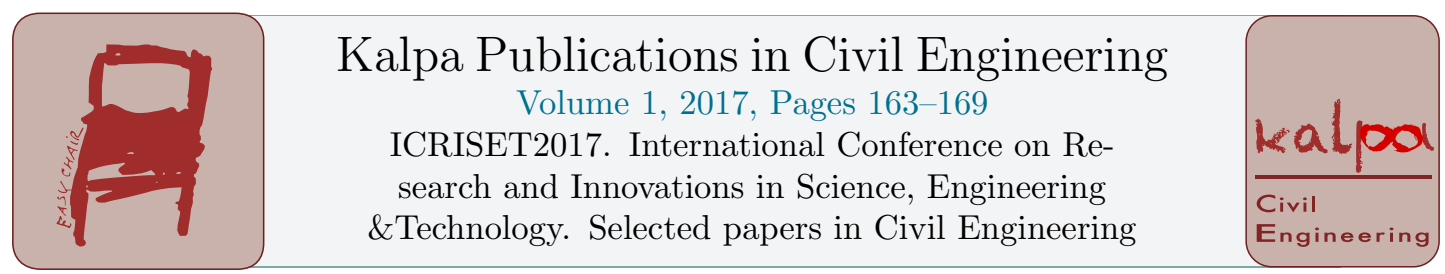

\title{
Influence of Mall on Trip Generating Area
}

\author{
Neha P. Bali ${ }^{1}$, DR. L. B. Zala ${ }^{2}$ \\ M.Tech. Student, Department of Civil Engineering, BVM \\ Engineering College, Vallabh Vidhyanagar, Anand, \\ India. $^{1}$ \\ Professor \& Head, Department of Civil Engineering, BVM \\ Engineering College, Vallabh Vidhyanagar, Anand, India ${ }^{2}$ \\ Email id:balineha27@gmail.com
}

\begin{abstract}
Trip Attraction is vital for planning of transportation facilities. It is utmost important for the planner to consider the influence of various development. The basic purpose of trip generation is to determine the number of trips that are generated or attracted to different zones. This paper seeks to build a suitable trip generation and attraction models for the selected malls of Vadodara city. Pilot survey has been done in order to determine trip attraction towards each mall. The analysis for the same is done through TransCAD software.
\end{abstract}

Key words: Trip generation model, Trip attraction model, multiple regressions, Malls.

\section{Introduction}

Urbanization is one of the major changes that a country experiences in its course of development. As a result of the former the standard of living of people has also improved.

In this process of urbanization development of shopping malls has played a major role. People have shifted from their older methods of shopping i.e. from individual retail outlets, provision stores etc towards this emerging mall culture as it fulfils all the needs under one roof.

The trip attraction rate of shopping mall is determined by considering the following factors i.e. time of the day, day of the week, season and the facilities and services provided by the shopping mall.The purpose of this study is to collect the data of the number of people coming to the various mall in the Vadodara city. 


\section{Need of the study}

The development of various commercial areas and the recreational malls in the city, have resulted into various traffic problems such as more trip attraction, increased traffic congestion in the area, and requirement for more parking spaces. Hence it is necessary to consider the increased trips attracted, so that efficient facilities for the faced problems can be worked out.

\section{Objectives of the study}

The objectives of the study are as follows:

The objective of the present work is confined to development of trip generation models for various malls in Vadodara city

To study the influence of shopping trips on traffic congestion, parking facilities and pedestrians.

\section{Scope of the study}

The scope of the present work is:

To collect the information of the study area in detail.

To collect preliminary data on trip making characteristics.

To understand different independent variables associated with the study.

Development of trip generation and attraction model using regression analysis

\section{Literature Review}

Trip generation analysis deals with predicting total number of trips that enter or leave a certain piece of land. The basic purpose of trip generation analysis is to develop a strong relationship between land use and trip purpose so that change in the land use can be used to estimate change in transportation demand.

Fillone and Tecson (2003): Developed models using multiple regressions which showed that floor area was one of the important aspects of trip attraction. Data included the data number of stores, parking lots, shopping mall floor area, number of floors.

Keefer (1966): examined the effects of shopping centre and trip maker characteristics on made to the selected centres. He formulated two models using linear regression. The model had independent variables such as number of parking spaces, number of work trips, distance from rival commercial establishment and built up area.

Pertina George and Gymmy Joseph Kattor (2013): formulated trip attraction model using for various town in Kerela. Data were collected through designed questionnaire. Origin-destination data were collected through socio-economic survey.

Navya S.V, Sanjay Kumar,Gymmy Joseph Kattoor (2013): developed trip generation model to determine factors that influence trip generation. They developed a mathematical model to show that trip generation is highly dependent upon employment status.

Karuturi Sasidhar, Yeluri Vineeth and S.S.V Subbarao (2016): analysed trip attraction rates in different cities of Andhra Pradesh. The factors taken into consideration were attributes of study area, number of employees, number of stores etc.

\section{Methodology}

The first step for building a trip generation and attraction models, seven shopping malls are selected in Vadodara city. The entire Vadodara city is divided into wards in order to simplify travel pattern. Pilot survey has been done in order to determine the number of trips attracted towards each shopping mall from different wards or area of the city.

A number of independent variables that influences trip attraction towards each mall are identified . 


\section{Study Area}

A total of seven shopping malls are selected from the Vadodara city. The positions of different malls are plotted using TransCAD software as shown in fig-1

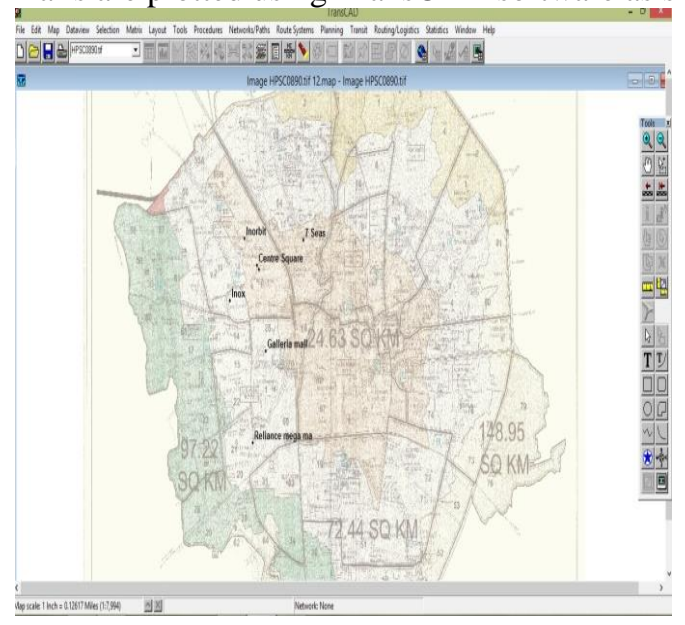

Fig-1 Location of shopping malls

The details of selected shopping malls are shown in the following table1:

Table-1 Mall Details

\begin{tabular}{|l|l|}
\hline Name of Malls & Location \\
\hline Inorbit Mall & Gorwa \\
\hline Centre square Mall & Genda Circle Alkapuri \\
\hline Vadodara central & Genda Circle Alkapuri \\
\hline 7 Seas Mall & Fathegunj \\
\hline Reliance Mega Mall & Old Padra Road \\
\hline Galleria Mall & Akota \\
\hline Inox & Race Course \\
\hline
\end{tabular}

\section{Data Collection}

Pilot survey has been conducted for determining trips attracted towards each mall by manual counts and the results are shown in table- 2 .

The dependent variable that is used for the analysis is the number of trips attracted to the shopping malls.

Sample size is selected according to Green (1991). The sample size for regression analysis is $\mathrm{N} \geq 50+8 \mathrm{~m}$ where $\mathrm{N}$ is the minimum number of a subjects and $\mathrm{m}$ is number of predictors.

For developing trip generation and attraction model questionnaire has been designed. The questionnaire consists of three parts.

Part-1 shows the house hold characteristics i.e. total number of family members, working members, school going children, vehicle ownership etc 
Part-2 shows the trip purpose i.e. Origin, destination, travel time, average distance, mode used and frequency of visit.

Part-3 shows shopping details which include the shopping activity, time spent at the mall etc.

As per the designed questionnaire the number of predictors are six i.e. distance, travel time, cost, income and activity (shopping, recreation, work) respectively. The sample size as per the formula is

$\mathrm{N} \geq 50+8(6)=50+48=98$. Therefore the sample size is 98

\begin{tabular}{|c|c|c|c|c|c|c|c|c|c|c|}
\hline \multirow[t]{2}{*}{$\begin{array}{l}\text { Name } \\
\text { of mall }\end{array}$} & \multirow{2}{*}{$\begin{array}{l}\text { Date } \\
\text { and } \\
\text { time }\end{array}$} & \multicolumn{2}{|c|}{$\begin{array}{l}\text { No. of trips } \\
\text { weekday* }\end{array}$} & \multirow{2}{*}{$\begin{array}{l}\text { Date } \\
\text { and } \\
\text { time }\end{array}$} & \multicolumn{2}{|c|}{$\begin{array}{l}\text { No. of trips } \\
\text { Weekend* }\end{array}$} & \multirow{2}{*}{$\begin{array}{l}\text { Par } \\
\text { kin } \\
\mathrm{g} \\
\mathrm{Sp} \\
\mathrm{ac} \\
\mathrm{e} \\
2- \\
\text { wh } \\
\text { eel } \\
\text { er }\end{array}$} & \multirow{2}{*}{$\begin{array}{l}\text { Parking } \\
\text { Space } \\
\text { 4- } \\
\text { Wheele } \\
\text { r }\end{array}$} & \multirow{2}{*}{$\begin{array}{l}\text { Capac } \\
\text { ity of } \\
\text { food } \\
\text { court } \\
\text { Sq ft }\end{array}$} & \multirow{2}{*}{$\begin{array}{l}\text { Floor } \\
\text { area } \\
\text { Lacs } \\
(\mathrm{sq} \mathrm{ft})\end{array}$} \\
\hline & & $\begin{array}{l}\text { Entr } \\
y\end{array}$ & $\begin{array}{l}\text { Ex } \\
\text { it }\end{array}$ & & $\begin{array}{l}\text { Entr } \\
\mathrm{y}\end{array}$ & $\begin{array}{l}\text { Ex } \\
\text { it }\end{array}$ & & & & \\
\hline 7 Seas & $\begin{array}{l}12 / 10 \\
/ 16 \\
4-5 \\
\mathrm{pm}\end{array}$ & 400 & $\begin{array}{l}25 \\
6\end{array}$ & $\begin{array}{l}15 / 10 \\
/ 16 \\
4-5 \\
\mathrm{pm} \\
\end{array}$ & 765 & $\begin{array}{l}43 \\
5\end{array}$ & $\begin{array}{l}40 \\
0\end{array}$ & 110 & 47000 & 1.85 \\
\hline Inorbit & $\begin{array}{l}10 / 10 \\
/ 16 \\
4-5 \\
\mathrm{pm}\end{array}$ & 628 & $\begin{array}{l}34 \\
5\end{array}$ & $\begin{array}{l}16 / 10 \\
/ 16 \\
4-5 \\
\mathrm{pm}\end{array}$ & $\begin{array}{l}112 \\
5\end{array}$ & $\begin{array}{l}75 \\
7\end{array}$ & $\begin{array}{l}35 \\
0\end{array}$ & 150 & 87000 & 4.05 \\
\hline $\begin{array}{l}\text { Vadod } \\
\text { ara } \\
\text { central }\end{array}$ & $\begin{array}{l}11 / 10 \\
/ 16 \\
4-5 \\
\mathrm{pm}\end{array}$ & 325 & $\begin{array}{l}20 \\
0\end{array}$ & $\begin{array}{l}21 / 10 \\
/ 16 \\
4-5 \\
\mathrm{pm}\end{array}$ & 745 & $\begin{array}{l}49 \\
5\end{array}$ & $\begin{array}{l}30 \\
0\end{array}$ & 70 & 4000 & 1.6 \\
\hline $\begin{array}{l}\text { Centre } \\
\text { Square }\end{array}$ & $\begin{array}{l}11 / 10 \\
/ 16 \\
5: 30- \\
6: 30 p \\
\mathrm{~m}\end{array}$ & 200 & $\begin{array}{l}17 \\
5\end{array}$ & $\begin{array}{l}21 / 10 \\
/ 16 \\
5: 30- \\
6: 30 p \\
\mathrm{~m}\end{array}$ & 590 & $\begin{array}{l}44 \\
2\end{array}$ & $\begin{array}{l}30 \\
0\end{array}$ & 50 & 13000 & 1.5 \\
\hline $\begin{array}{l}\text { Relian } \\
\text { ce } \\
\text { mega } \\
\text { mall }\end{array}$ & $\begin{array}{l}13 / 10 \\
/ 16 \\
4-5 \\
\mathrm{pm}\end{array}$ & 425 & $\begin{array}{l}37 \\
2\end{array}$ & $\begin{array}{l}22 / 10 \\
/ 16 \\
4-5 \\
\mathrm{pm}\end{array}$ & 850 & $\begin{array}{l}55 \\
2\end{array}$ & $\begin{array}{l}30 \\
0\end{array}$ & 100 & 30000 & 1.97 \\
\hline $\begin{array}{l}\text { Galleri } \\
\text { a Mall }\end{array}$ & $\begin{array}{l}13 / 10 \\
/ 16 \\
5: 30- \\
6: 30 p \\
m\end{array}$ & 250 & $\begin{array}{l}20 \\
0\end{array}$ & $\begin{array}{l}22 / 10 \\
/ 16 \\
5: 30- \\
6: 30 p \\
\mathrm{~m}\end{array}$ & 675 & $\begin{array}{l}57 \\
3\end{array}$ & $\begin{array}{l}30 \\
0\end{array}$ & 40 & 6000 & 1.87 \\
\hline Inox & $\begin{array}{l}12 / 10 \\
/ 16 \\
5: 30- \\
6: 30 \mathrm{p} \\
\mathrm{m}\end{array}$ & 275 & $\begin{array}{l}19 \\
0\end{array}$ & $\begin{array}{l}15 / 10 \\
/ 16 \\
5: 30- \\
6: 30 p \\
m\end{array}$ & 690 & $\begin{array}{l}42 \\
5\end{array}$ & $\begin{array}{l}25 \\
0\end{array}$ & 50 & 2500 & 1.45 \\
\hline
\end{tabular}

Table-2 Results of pilot survey 
*The number of trips at entry and exit will be equal if observed from opening of mall to the closing of mall.

The analysis of the following results is shown below:

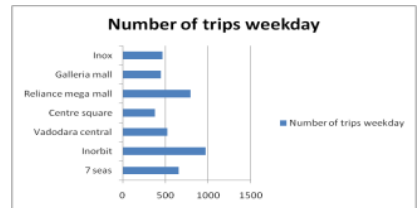

Fig-2 Number of trip weekday

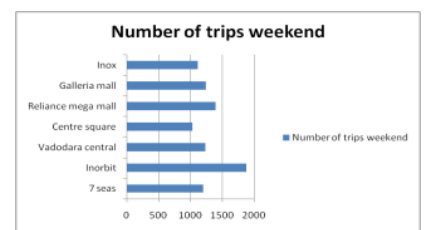

Fig-3 Number of trips weekend

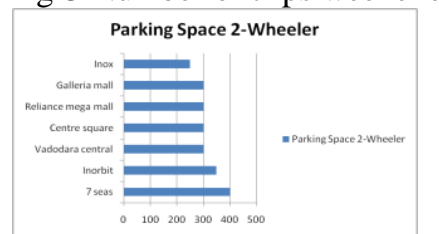

Fig-4 Parking Space 2-Wheeler

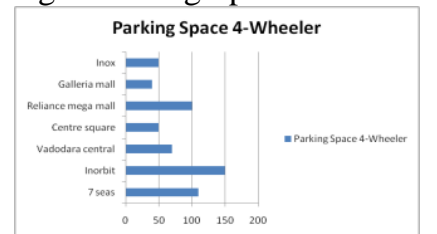

Fig-5 Parking Space 4-Wheeler

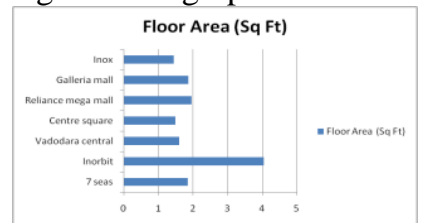

Fig-6 Floor Area

\section{Regression Analysis}

The model is developed through multiple regression analysis with the independent variables as parking Space for 4 wheeler and food court/ restaurant area of the selected malls.

The predictive equation from multiple regression analysis is:

$\mathrm{Y}=45.253+\left(3.974 \mathrm{x}_{2}\right)+\left(-0.00084 \mathrm{x}_{4}\right)$ 
Where,

$\mathrm{y}=$ trips attracted to the mall

$\mathrm{x}_{2}=$ Parking space for 4 -wheeler

$\mathrm{x}_{4}=$ Food court/ restaurant area

The first term in the prediction equation (45.253) is a constant that represent the predicted criterion value. The values 3.974 and -0.00084 represent regression weights or regression weights or regression coefficients of the selected independent variables, parking space 4wheeler and food court/ restaurant area. The negative coefficient for $\mathrm{x}_{4}$ is improper which needs further detail study.

Table-3 Regression Statistics

\begin{tabular}{|l|l|}
\hline Multiple R & 1 \\
\hline R Square & 1 \\
\hline Adjusted R-Square & 65535 \\
\hline Standard error & 0 \\
\hline Observation & 3 \\
\hline
\end{tabular}

Table-4 Annova Result

\begin{tabular}{|l|l|l|l|}
\hline & df & SS & MS \\
\hline Regression & 4 & 17849.74 & 4462.435 \\
\hline Residual & 0 & 0 & 65535 \\
\hline Total & 4 & 17849.74 & \\
\hline
\end{tabular}

10. The data from interview indicates average distance or a trip length from mall location to origin is $6.5 \mathrm{~km}$. The maximum length of trip is $13 \mathrm{~km}$ observed.

\section{Conclusion}

This study gives a brief idea about the factors affecting trip attraction i.e floor area of mall, number of stores, food court capacity towards the shopping malls. The parking facility at mall is major factor affecting trip attraction. The influence of mall in trip attraction on an average ranges above $6.0 \mathrm{~km}$ radius.

ANNEXURE-A

B.V.M ENGINEERING COLLEGE V.V. NAGAR

CIVIL ENGINEERING DEPARTMENT

COURSE: M-TECH TRANSPORTATION SYSTEM ENGINEERING

FORM NO:

DATE: / / 2016-17

PART-1 HOUSEHOLD INFORMATION

ADDRESS:

WARD NO:

TOTAL MEMBERS IN FAMILY: $\mathrm{M}$ $\mathrm{F}$ HOUSEHOLD MONTHLY INCOME: $<=$ Rs 6000 
Rs 6000-15,000

Rs 15,000-40,000

Rs 40,000-60,000

$>=$ Rs 60,000

PART-2 TRIP DETAILS

\begin{tabular}{|l|l|l|l|l|l|l|}
\hline ORIGIN & $\begin{array}{l}\text { DISTANCE } \\
\text { IN KM }\end{array}$ & $\begin{array}{l}\text { TRAVEL } \\
\text { TIME }\end{array}$ & $\begin{array}{l}\text { TRAVEL } \\
\text { COST }\end{array}$ & MODE & \multicolumn{2}{|l|}{ FREQUENCY } \\
\cline { 5 - 7 } & & & & & $\mathrm{W}$ & $\mathrm{M}$ \\
\hline
\end{tabular}

W- WEEKELY M-MONTHLY

PART-3 SHOPPING DETAILS

What is the main activity for which you have visited this shopping mall:

Shopping:1. Grocery 2. Clothing 3. Electronic appliances 4. Foot wear 5. Accessories

Recreation: 1. Food court/Restaurant 2. Multiplex 3. Game zone

Work

Others

How long have you spent here today:

$<=30$ mins

30mins-1 hour

1 hour-2 hour

2 hour- 3 hour

3 hour- 5 hour

$>=5$ hours

What do you particularly like about this mall:
Cost/Price
b) Product varieties
c) Ambiance
d) Accessibility
e) Vending

Services f) Discounts

What aspect do you think need to be improved:
a) Parking
b) Vending Services
c) Ambiance
d) Customer Care
e) Security

\section{References}

- A.M Fillone and M.R Tecson(2003) "Trip Attraction of mixed use Development in Metropolitan Manila" Eastern Asia Society for Transp Studies Vol.4 October 860-868

- Keefer, L.E (1996) Urban Travel Pattern for airports, shopping centers and industrial plants, Highway Research Board, National Academy of Sciences-National Academy of Engineering

- Karuturi Sasidhar, Yeluri Vineeth and S.S.V Subbarao (2016) "Trip Attraction Rates Of Commercial Land Use" Indian Journal of Science and Technology Vol-9 Area Of Thiruvananthapram City" International Journal of Research in Engineering and Technology Vol-2 issue 1

- Pretina George , Gymmy Joseph Kattor (2013) "Forecasting Trip Attraction Based On Commercial Land Use Charateristics" International Journal of Research in Engineering and technology vol-2 issue 9.

- Samuel B. Green (1991), “ How many subject does it take to do a regression analysis, Multivariate Behavioural Research Pg 499-510. 